\title{
Pengaruh Model Pembelajaran PACE (Project, Activity, Cooperative Learning, Exercise) Terhadap Kemampuan Pemecahan Masalah Matematis Ditinjau Dari Gaya Belajar Peserta Didik
}

\author{
Syeppina Dwiyani ${ }^{1}$, Syaiful ${ }^{2}$, Haryanto ${ }^{3}$ \\ 1, 2,3 Program Studi Magister Pendidikan Matematika, Fakultas Pascasarjana, Universitas Jambi, \\ Jl. Jambi-Muaro Bulian KM.15 Mandalo Indah Muaro Jambi, Jambi, Indonesia \\ syeppinadwiyani@gmail.com
}

\begin{abstract}
Differences in learning styles are one of the important variables and are related to the way students understand lessons at school, especially mathematics. The purpose of this study was to see the interaction between the PACE learning model and learning styles in influencing students' mathematical problem solving' abilities. The research used quasi experimental, this research design using the Non-Equivalet Control Group Design. This research was conducted at SMAN 4 Sarolangun in class X semester II. The sample in this study was taken from a part of the population, the population was tested first by means of the normality and homogeneity test to obtain a representative sample.The instrument used was the problem solving and mathematical communication skills test in the form of a test question and also used a questionnaire to see the differences in learning styles of students. Data analysis techniques with twoway ANOVA variations. The results of the two-way ANOVA test had a significance value of $0.98<0.05$. The conclusion in this study is that there is not an interaction between the PACE learning model and learning styles in influencing students' mathematical problem solving's abilities.
\end{abstract}

Keywords: PACE model, Mathematical Problem Solving, learning style

\begin{abstract}
Abstrak
Perbedaan gaya belajar merupakan salah satu variabel yang penting dan menyangkut dengan cara siswa memahami pelajaran di sekolah khususnya pelajaran matematika. Tujuan penelitian ini untuk melihat interaksi antara model pembelajaran PACE dan gaya belajar dalam mempengaruhi kemampuan pemecahan masalah matematis peserta didik. Penelitian yang digunakan adalah quasi experimental, desain penelitian ini menggunakan Non-Equivalet Control Group Design. Penelitin ini dilaksana di SMAN 4 Sarolangun pada kelas X semester II. Sampel dalam penelitian ini diambil dari bagian dari populasi, populasi diuji terlebih dahulu dengan uji normalitas dan homogenitas didapatlah sampel yang representatif. Instrumen yang digunakan tes kemempuan pemecahan masalah dan komunikasi matematis berupa tes soal dan juga menggunakan angket melihat perbedaan gaya belajar peserta didik. Teknik analisis data dengan variasi ANOVA dua jalur. Hasil uji ANOVA dua jalur nilai signifikansinya $0.98<0.05$. Kesimpulan dalam penelitian ini tidak terdapat interaksi antara model pembelajaran PACE dan gaya belajar dalam mempengaruhi kemampuan pemecahan masalah matematis peserta didik.
\end{abstract}

Kata kunci: model PACE, Pemecahan Masalah Matematis, Gaya Belajar

Copyright (c) 2021 Syeppina Dwiyani, Syaiful, Haryanto

$\triangle$ Corresponding author: Haryanto

Email Address: Haryanto.fkip@unja.ac.id (J1. Jambi-Muaro Bulian KM.15 Mandalo Indah Muaro Jambi)

Received 10 Juni 2021, Accepted 22 Juni 2021, Published 23 Juni 2021

\section{PENDAHULUAN}

Pembelajaran matematika di sekolah diharapkan agar peserta didik dapat menumbuh kembangkan kemampuan berpikir secara matematis dan dasar pengetahuan matematika. Menurut National Council of Teachers Mathematics atau NCTM (NCTM, 2000) mengungkapkan bahwa dalam belajar matematika, peserta didik harus memiliki kemampuan pemecahan masalah, penalaran dan bukti, komunikasi, koneksi dan representasi. Hal yang sama diungkapkan dalam Permendikbud No 21 Tahun 2016 tentang Standar Isi Pemdidikan Dasar dan Menengah bahwa pembelajaran matematika bertujuan agar peserta didik memiliki kecakapan atau kemahiran matematika sebagai bagian dari kecakapaan hidup yang harus dimiliki peserta 
didik terutama dalam pengembangan penalaran, komunikasi, dan pemecahan masalah (problem solving) yang dihadapi dalam kehidupan sehari-hari (Permendikbud, 2016)

Berdasarkan tujuan pembelajaran matematika menurut NCTM dan Permendikbud di atas, menunjukkan bahwa pentingnya peserta didik untuk memiliki serta mengembangkan kemampuan pemecahan masalah dalam pembelajara matematika. Hal ini senada diungkapkan oleh (Ersoy, 2016) bahwa pentingnya bagi peserta didik untuk memiliki kemampuan pemecahan masalah matematis karena akan mambantunya mempermudah dalam menyelesaikan berbagai macam bentuk permasalahan matematika.

Berdasarkan observasi di lapangan, pembelajaran Matematika di SMAN 4 Sarolangun sejauh ini dapat dikatakan berjalan baik. Mengajar bagaimana memecahkan masalah beberapa guru mempunyai cara yang berbeda-beda, diantaranya dengan selalu memberikan contoh-contoh bagaimana menyelesaikan masalah matematika dan memberikan kesempatan kepada siswa untuk mencari sendiri penyelesaiannya. Secara umum dalam proses pembelajaran sudah ditetapkan sebuah ketuntasan belajar. Namun hasil matematika siswa belum mencapai hasil yang maksimal atau belum mencapai KKN yang sudah ditetapkan yaitu 75. Soal matematika yang mengukur aspek pemecahan masalah dapat diselesaikan dengan menggunakan langkah-langkah yaitu (1) Understanding the problem (memahami masalah); (2) Menyusun rencana (perencanaan Strategi); (3) Melaksanakan rencana (menerapkan strategi) (4) Periksakan kembali (melihat kebelakang) (Putra et al., 2020). Peserta didik tidak dapat memahami informasi yang diberikan serta tidak mengetahui permasalahan yang diberikan dengan contoh yang dijelaskan oleh guru. Rendahnya kemampuan pemecahan masalah matematis peserta didik dapat dilihat dari mereka menyelesaikan suatu soal yang berhubungan dengan soal cerita pada materi persamaan linear dua dan tiga variabel.

Soal nomor 1. Shaffa memiliki tiga buah balok angka. Setiap balok tersebut memiliki angka yang berbeda. Jika jumlah tiga bilangan sama dengan 45, bilangan pertama ditambah 4 sama dengan bilangan kedua, dan bilangan ketiga dikurangi 17 sama dengan bilangan pertama. Tentukanlah masing-masing bilangan tersebut. Selesaikanlah dengan menggunakan langkah-langkah pemecahan masalah!

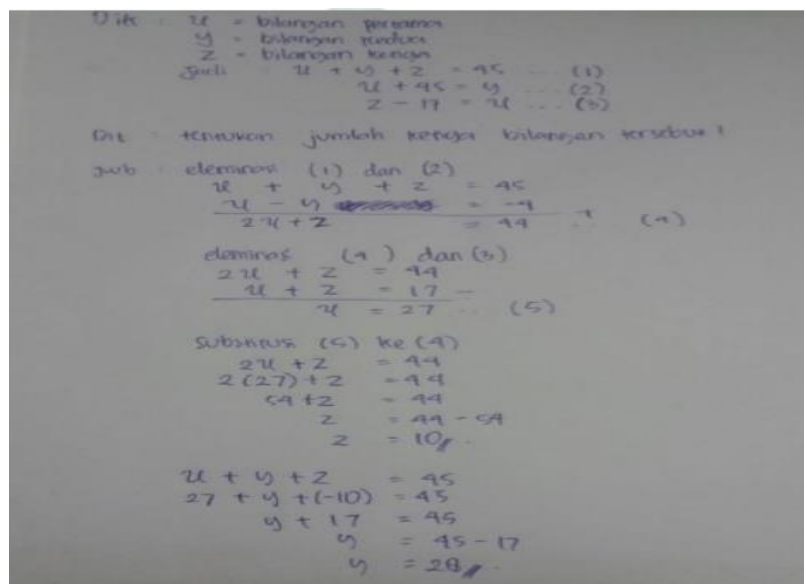

Gambar 1. Jawaban Soal No 1 
Dari jawaban siswa di atas, terlihat bahwa siswa sudah melakukan langkah pertama dalam pemecahan masalah yaitu memahami masalah dengan menuliskan unsur-unsur yang diketahui dan ditanyakan pada soal, namun siswa tidak teliti saat menuliskan model matematika. Hal tersebut terlihat pada Gambar di atas pada saat membuat model matematika untuk persamaan kedua.

Soal nomor 2. Ibu dan Aminah membutuhkan gula pasir dan tepung terigu untuk membuat kue pesanan. Ibu membeli dua kg gula pasir dan lima kg tepung terigu yang harus dibayar Rp. 55.000,-. Setelah selesai berbelanja, ternyata ibu kekurangan bahan adonan setengah $\mathrm{kg}$ gula pasir dan satu $\mathrm{kg}$ tepung terigu. Ibu meminta Aminah untuk membelinya di minimarket terdekat. Pada brosur minimarket tersebut dituliskan bahwa harga satu kg terigu adalah satu pertiga dari harga satu kg gula pasir. Jika Aminah membawa uang Rp. 20.000,-. Berapakah uang kembalian yang diterima Aminah? Selesaikanlah dengan menggunakan langkah-langkah pemecahan masalah!

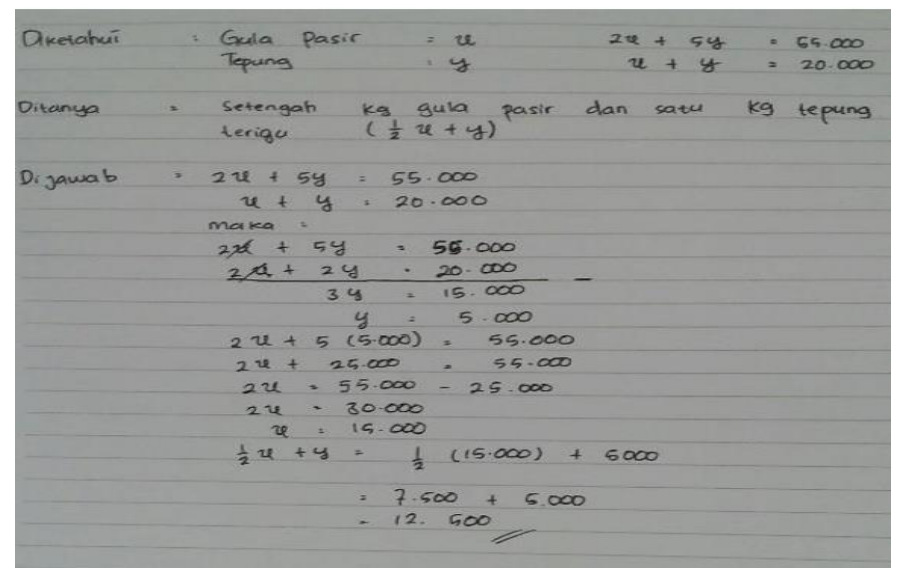

Gambar 2. Jawaban Soal No 2

Dari jawaban siswa di atas, terlihat bahwa siswa sudah melakukan langkah pertama dalam pemecahan masalah yaitu memahami masalah dengan menuliskan unsur-unsur yang diketahui dan ditanyakan pada soal. Siswa mampu menuliskan pemisalan pada tepung terigu dan gula, namun masih terjadi kesalahan pada saat merubah kalimat menjadi model matematika.

Berdasarkan persentase hasil jawaban siswa pada soal nomor 1 dan nomor 2, dapat disumpulkan bahwa siswa masih lemah dalam kemampuan pemecahan masalah. Berdasarkan nilai ujian semester ganjil pada bulan desember 2020 yang diperoleh menunjukkan bahwa hasil ujian semester ganjil peserta didik masih jauh dari yang diharapkan. Selain itu juga, soal ujian matematika yang diberikan masih termasuk bentuk soal yang sederhana. Jadi, dapat disimpulkan bahwa kemampuan pemecahan masalah dan komunikasi matematis peserta didik masih belum berkembang secara optimal.

Salah satu penyebab belum berkembangnya kemampuan pemecahan masalah peserta didik karena cara mengolah pembelajaran yang masih belum memberikan banyak kesempatan pada peserta didik dalam mengembangkan kemampuan pemecahan masalah matematis (Sundayana, 2016). Alternatif untuk mengembangkan kemampuan pemecahan masalah dengan mengelola kegiatan pembelajaran menerapkan 
model PACE. Model PACE dalam pembelajarannya akan jauh lebih terlibat dalam pembelajaran aktif melalui kerja kelompok dan diskusi. Model pembelajaran PACE didasarkan pada prinsip seperti yang dikemukakan oleh Lee (Fadlurreja, Dewi, et al., 2019). Penerapan model PACE ini sangat penting bagi guru untuk melihat karakteristik peserta didik dalam proses pembelajarn, karakteristik disini adalah gaya belajar seseorang.

Perbedaan gaya belajar merupakan salah satu variabel yang penting dan menyangkut dengan cara siswa memahami pelajaran di sekolah khususnya pelajaran matematika. Oleh karena itu gaya belajar siswa yang berbeda maka sangat penting bagi guru untuk dapat mengetahui gaya belajar setiap peserta didik sehingga menjadi salah satu hal penting yang akan diperhatikan dalam menerapkan model pembelajaran PACE (Rachmawati et al., 2018), untuk membantu membentuk suatu kelompok belajar yang heterogen agar peserta didik dapat saling membantu satu sama lain. Oleh karena itu, penting bagi guru untuk mempertimbangkan gaya belajar peserta didik terlebih dahulu sebelum memulai proses pembelajaran agar dapat mencapai hasil yang optimal.

Untuk mengatasi kurang terlatihnya siswa dalam menyelesaikan suatu permasalahan yang diberikan oleh pendidik, maka diperlukan suatu model pembelajajaran yang dapat diterapkan dalam proses pembelajaran yang kontekstual sehingga dapat membantu peserta didik untuk meningkatkan kemampuan pemecahan masalah. Oleh karena itu, perlu dilakukan penerapan model yang sesuai dengan pemecahan masalah salah satu model yang dipilih adalah model pembelajaran PACE (project, activity, cooperative learning, exercise).

Model pembelajaran PACE merupakan singkatan dari project (proyek), activity (aktivitas), cooperative learning (pembelajaran kooperatif), exercise (latihan). PACE merupakan suatu pola acuan belajar dan mengajar yang meliputi empat kegiatan (Fadlurreja, Dewi, N., et al., 2019). Dengan model pemebaljaran PACE agar menuntut peserta didik berperan aktif selama pembelajaran berlangsung. Proyek merupakan komponen penting dari model PACE, mengtakan bahwa proyek merupakan bentuk pembelajaran yang inovatif yang menekankan pada kegiatan kompleks dengan tujuan pemecahan masalah yang berdasarkan pada kegiatan aktivitas peserta didik.

Aktivitas dalam model PACE bertujuan untuk mengenalkan siswa terhdap informasi atau konsep yang baru sebagai panduan siswa dalam mempelajari materi dan mengerjakan soal yang berhubungan dengan pemcahan masalah matematis yang akandi pelajari (Raharjo, 2017). Pembelajaran kooperatif dalam model PACE adapun peranan sebagai panduan siswa dalam mempelajari materi dan mengerjakan soal-soal dan siswa diberikesempatan untuk menemukan sendiri konsep yang akan dipelajari.

Latihan dalam model PACE bertujuan untuk memperkuat konsep yang telah dikontruksi pada tahapa ktivitas dan pembelajaran kooperatif dalam bentuk penyelesaiansoal. Karna model pembelajaran PACE cocok untuk melatih dan mengambangkan kemampuan pemecahan masalah. Gaya belajar yang di pakaiada 3 yaitu : visual, auditori dan kinestetik. Karena ada karakteristik yang ditinjau dari masing-masing gaya belajar dan juga memiliki kelebihan dan kekurangan dari masing-masing gaya belajar tersebut. 
Penting memperhatikan gaya belajar peserta didik saat menerapkan model pembelajaran karena akan memberikan pengaruh terhadap kemampuan pemecahan masalah matematis. Peserta didik yang memiliki gaya belajar visual memiliki banyak cara untuk menyampaikan ide atau gagasan yang dimiliki dalam menyelesaikan masalah matematika dibandingkan dengan peserta didik yang memiliki gaya belajar auditori dan kinestetik (Danaryanti \& Noviani, 2015).

Perbedaan gaya belajar merupakan salah satu variabel yang penting dan menyangkut dengan cara peserta didik memahami pelajaran di sekolah, oleh karena itu gaya belajar siswa yang berbeda maka sangat penting bagi guru untuk dapat mengetahui gaya belajar setiap peserta didik sehingga menjadi salah satu hal yang penting salam menerapkan model PACE untuk membantu membentuk suatu kelompok belajar yang heterogen agar peserta didik dapat membantu satu sama lain. Oleh karena itu, penting bagi guru untuk mempertimbangkan gaya belajar peserta didik terlebih dahulu sebelum memulai proses pembelajaran agar dapat mencapai hasil yang oktimal. Tujuan penelitian ini untuk melihat interaksi antara model pembelajaran PACE dan gaya belajar dalam mempengaruhi kemampuan pemecahan masalah matematis peserta didik.

\section{METODE}

Penelitian yang digunakan adalah quasi experimental, menggunakan desain penelitian Nonequivalent Control Group DesignI untuk melihat pengaruh model PACE terhadap kemampuan pemecahan masalah matematis peserta didik. Penelitian ini terlaksana di SMAN 4 Sarolangun pada tanggal 22 Maret22 April 2020 di kelas X semester II (genap) Tahun Ajaran 2020/2021 pada materi Statistika.

Populasi dalam penelitian ini seluruh peserta didik kelas di SMAN 4 Sarolangun pada Tahun Ajaran 2020-2021 berjumlah 155 orang. Teknik pengambilan sampel dengan cara simple random samling, sampel terlebih dahulu di uji normalitas dan homogenitas. Uji normalitas dan homogenitas dengan menggunakan program SPSS. Berikut hasil uji normalitas dan homogenitas:

Tabel 1. Normalitas Data Populasi

\begin{tabular}{|l|r|r|r|r|r|r|}
\hline & \multicolumn{3}{|c|}{ Kolmogorov-Smirnov $^{\text {a }}$} & \multicolumn{3}{c|}{ Shapiro-Wilk } \\
\cline { 2 - 8 } & Statistic & \multicolumn{1}{|c|}{ df } & \multicolumn{1}{c|}{ Sig. } & Statistic & \multicolumn{1}{c|}{ df } & \multicolumn{2}{c|}{ Sig. } \\
\hline X1 & .136 & 29 & .184 & .957 & 29 & .277 \\
\hline X2 & .140 & 29 & .150 & .945 & 29 & .139 \\
\hline X3 & .166 & 29 & .041 & .949 & 29 & .169 \\
\hline X4 & .139 & 29 & .158 & .934 & 29 & .068 \\
\hline X5 & .163 & 29 & .048 & .941 & 29 & .109 \\
\hline
\end{tabular}

Tabel 2. Homogenitas Data Populasi

\begin{tabular}{|r|r|r|r|}
\hline Levene Statistic & df1 & df2 & Sig. \\
\hline 2.047 & 4 & 150 & .091 \\
\hline
\end{tabular}

Berdasarkan Tabel 1 terlihat pada bagian kolom Shapiro-wilk niali signifikannsinya $<0.05$. Maka disinpulkan populasi berdistribusi normal. Sedangkan pada Tabel 2 terlihat hasil nilai signifikansinya < 0.05. Maka dapat disimpulkan populasi berdistribusi homogen. Setelah didapat hasil populasi berdistribusi 
normal dan homogen, maka selanjutnya pengambilan sampel dengan tekni simple random sampling. Sanpel penelitian di kelas eksperimen I diterapkan model pembelajaran PACE di kelas X-1, kelas eksperimen II diterapkan model pembelajaran PACE ditambah media di kelas X-2, dan kelas kontrol diterapkan pembelajaran konvensional di kelas X-3. Variabel dalam penelitian ini yaitu variabel bebas adalah model pembelajaran PACE, variabel terikat kemampuan pemecahan masalah matematis peserta didik dan variabel moderator perbedaan gaya belajar.

Prosedur penelitian ada 3 yaitu tahap persiapan, pelaksanaan dan penyelesaiyan. Tahap persiapan 1) Studi pendahuluan dimana melakukan studi literatur terhadap teori yang relevan mengenai pembelajaran di SMAN 4 Sarolangun, serta menganalisis kurikulum. 2) Menetapkan jadwal penelitian. 3) Menentukan kelas sampel penelitian. 4) Mempersiapkan Rencana Pwlaksanaan Pembelajaran (RPP). 5) Mempersiapkan Lembar Kerja Peserta Didik (LKPD). 6) Mempersiapkan instrumen penelitian. 7) Memvalidasi RPP, LKPD dan istrumen penelitian. 8) memberikan angket gaya belajar kepada peserta didik sebelum diterapkan model PACE dalam pembelajaran. Tahap pelaksanaan terlihat pada Tabel 3 sebagai berikut:

Tabel 3. Tahap Pelaksanaan Kelas Eksperimen dan Kelas Kontrol

\begin{tabular}{|c|c|c|}
\hline No & $\begin{array}{l}\text { Kelas Eksperimen dengan } \\
\text { Pembelajaran PACE }\end{array}$ & $\begin{array}{c}\text { Kelas Kontrol dengan } \\
\text { Pembelajaran Konvensional }\end{array}$ \\
\hline 1 & $\begin{array}{l}\text { Project (proyek) } \\
\text { Guru memberikan tugas proyek kepada peserta } \\
\text { didik yang dikerjakan dalam bentuk kelompok. } \\
\text { Mereka diminta untuk mencari } \\
\text { solusi/penyelesaian daripermasalahan dalam } \\
\text { kehidupan nyata yang berkaitan dengan topik } \\
\text { pembelajaran yang sedang dipelajari. Mereka } \\
\text { diharuskan membuat laporan dari proyek yang } \\
\text { dikerjakan dan dikumpulkan pada waktu tertentu } \\
\text { sesuai dengan kesepakatan antara guru dan } \\
\text { peserta didik. }\end{array}$ & $\begin{array}{l}\text { Mengamati } \\
\text { Guru memberikan masalah kepada peserta } \\
\text { didik. Mereka diminta untuk mengamati } \\
\text { kejadian, peristiwa, situasi, pola, } \\
\text { fenomena yang terkait dengan matematika } \\
\text { dan mulai dikenalkan pemodelan } \\
\text { matematika dalam berbagai bentuk. }\end{array}$ \\
\hline 2 & $\begin{array}{l}\text { Activity (aktivitas) } \\
\text { Guru mengecek LKT peserta didik untuk } \\
\text { mengetahui apakah dikerjakan di rumah atau } \\
\text { tidak sebelum pembelajaran. Selanjutnya, guru } \\
\text { bertanya kepada peserta didik mengenai konsep } \\
\text { yang akan dibahas dalam rangka meningkatkan } \\
\text { pemahaman konsep dan memberikan bimbingan } \\
\text { jika terjadi miskonsepsi. }\end{array}$ & $\begin{array}{l}\text { Menanya } \\
\text { Guru memberi kesempatan kepada peserta } \\
\text { didik untuk mengajukan pertanyaan atau } \\
\text { masalah yang terkait dengan data dan } \\
\text { informasi yang dikumpulkan, misal } \\
\text { dengan mempertanyakan mengapa atau } \\
\text { bagaimana fenomena bisa terjadi. }\end{array}$ \\
\hline 3 & $\begin{array}{l}\text { Cooperatif Learning (kooperatif) } \\
\text { Guru memberikan LKD ke setiap kelompok } \\
\text { terkait dengan materi yang dibahas. Ini } \\
\text { merupakan kelanjutan dari LKT dan memiliki } \\
\text { tingkat kesulitan yang lebih tinggi. Peserta didik } \\
\text { berkesempatan untuk mengemukakan temuan- } \\
\text { temuan yang diperoleh pada saat diskusi agar } \\
\text { terjadi pertukaran informasi sehingga } \\
\text { terbentukpemahaman yang benar terhadap suatu } \\
\text { konsep. }\end{array}$ & $\begin{array}{l}\text { Mengumpulkan } \\
\text { Guru memberikan ruang kepada peserta } \\
\text { didik untuk mengumpulkan dan atau } \\
\text { menggali informasi melalui mencoba, } \\
\text { mengkaji, serta mendiskusikan untuk } \\
\text { mendalami konsep yang terkait dengan } \\
\text { fenomena tersebut. }\end{array}$ \\
\hline 4 & $\begin{array}{l}\text { Exercise (latihan) } \\
\text { Guru memberikan tugas tambahan } \\
\text { memperkuat untuk } \\
\end{array}$ & $\begin{array}{l}\text { Menganalisis } \\
\text { Guru memberikan kesepatan kepad } \\
\text { peserta didik untuk melakukan asosias }\end{array}$ \\
\hline
\end{tabular}


Pengaruh Model Pembelajaran PACE (Project, Activity, Cooperative Learning, Exercise) Terhadap Kemampuan Pemecahan Masalah Matematis Ditinjau Dari Gaya Belajar Peserta Didik, Syeppina Dwiyani, Syaiful, Haryanto

\begin{tabular}{|c|l|l|}
\hline No & \multicolumn{1}{|c|}{ Kelas Eksperimen dengan } & \multicolumn{1}{|c|}{$\begin{array}{l}\text { Kelas Kontrol dengan } \\
\text { Pembelajaran PACE }\end{array}$} \\
\hline & $\begin{array}{l}\text { dikonstruksi pada tahap aktivitas dan Konvensional } \\
\text { pembelajaran kooperatif dalam bentuk } \\
\text { penyelesaian soal-soal. }\end{array}$ & $\begin{array}{l}\text { atau menganalisis secara kritis dalam } \\
\text { menjelaskan keterkaitan antar konsep dan } \\
\text { menggunakan, memanfaatkan dalam } \\
\text { memilih prosedur/algoritma yang sesuai, } \\
\text { menyusun penalaran dan generalisasi. }\end{array}$ \\
\hline
\end{tabular}

Tahap penyelesaian 1) Memberikan tes kemampuan pemecahan masalah dan komunikasi matematis pada kelas esperimen dan kelas kontrol dengan soal yang sama. 2) Mengolah dan menganalisis data yang diperoleh sesuai dengan analisis data yang digunakan. 3) Menarik kesimpulan dari hasil yang diperoleh sesuai dengan pengujian hipotesis yang digunakan. 4) Menyusun laporan penelitian. Istrumen yang digunakan berupa soal tes kemampuan pemecahan masalah matematis dan angket gaya belajar. Instrumen yang digunakan terlebih dahulu divalidasi oleh ahli sebelum di ujikan kepada peserta didik. Teknik analisis data dengan uji ANOVA dua jalur mengunakan program SPSS.

\section{HASIL DAN DISKUSI}

Penelitian ini merupkan penelitian kuntitatif dengan menggunakan metode penelitian esperimen. Desai penelitian yang digunakan adalah desain faktorial 3x3, penelitian ini di lakukan pada tiga kelas yaitu 2 kelas eksperimen dan 1 kelas kontrol. Kelas eksperimen 1 yaitu kelas X-1 menerapkan model pembelajaran PACE, pada kelas eksperimen 2 yaitu kelas -2 menggunakan model pembelajaran PACE dengan media pembelajaran, dan kelas kontrol yaitu X-3 menggunakan menggunakan metode konvensional.

Sebelum setiap kelas diberikan perlakuan, terlebih dahulu setiap kelas diuji menggunakan soal pretest. Soal pretest untuk mengetahui kemampuan pemecahan masalah matematis peserta didik. Sebelum di uji soal tes di validasi terlabih dahulu dengan ahli, kemudian seoal tes di uji validitas soal, reliabilitas soal, dan daya beda soal.

Tabel 4. Hasil Validitas Soal Tes

\begin{tabular}{|c|c|c|c|c|}
\hline Nomor Soal & Nilai $r_{\text {hitung }}$ & Nilai $t_{\text {hitung }}$ & Nilai $t_{\text {tabel }}$ & Kriteria Soal \\
\hline 1 & 0,869 & 9,024 & 1,725 & Valid \\
\hline 2 & 0,482 & 2,460 & 1,725 & Valid \\
\hline 3 & 0,652 & 3,846 & 1,725 & Valid \\
\hline
\end{tabular}

Pada Tabel 4 terlihat bahwa tiga butir soal tes kemampuan pemecahan masalah matematis seluruhnya memperoleh nilai $t_{\text {hitung }}$ lebih besar dibandingkan nilai $t_{\text {tabel }}$ atau $t_{\text {hitung }}>t_{\text {tabel. }}$. Sehingga dapat disimpulkan bahwa soal tes kemampuan pemecahan masalah matematis pada nomor 1, 2, dan 3 dinyatakan valid. Perhitungan validitas butir soal tes kemampuan pemecahan masalah matematis. 
Tabel 5. Hasil Reabilitas Soal Tes

\begin{tabular}{|c|c|c|}
\hline Butir Soal Tes & Nilai $\boldsymbol{r}_{\mathbf{1 1}}$ & Kriteria Soal \\
\hline Pemecahan Masalah Matematis & 0,75 & Reliabilitas Tinggi \\
\hline
\end{tabular}

Terlihat pada Tabel 5 nilai $\mathrm{r}_{11}=0.75$ untuk butir tes kemampuan pemecahan masalah matematis. Hal ini menunjukkan bahwa tes kemampuan pemecahan masalah mempunyai reliabilitas tinggi. Perhitungan uji reliabilitas butir soal tes kemampuan pemecahan masalah matematis.

Tabel 6. Hasil Indeks Daya Pembeda Butir Soal Tes

\begin{tabular}{|c|c|c|}
\hline Nomor Soal & Nilai $\boldsymbol{I}_{\boldsymbol{p}}$ & Kriteria Soal \\
\hline 1 & 0,50 & Sangat baik \\
\hline 2 & 0,36 & Baik \\
\hline 3 & 0,44 & Sangat baik \\
\hline
\end{tabular}

Pada Tabel 6 terlihat bahwa soal tes kemampuan pemecahan masalah matematis pada nomor 1 dan 3 memperoleh nilai $I_{p} \geq 0.40$ yang termasuk dalam kategori sangat baik, sedangkan soal pada nomor 2 memperoleh nilai $0.30<\mathrm{I}_{\mathrm{p}} \leq 0.39$ yang termasuk pada kategori baik. Setelah dinyatakan valid soal tes di uji kepada setiap kelas dengan soal yang sama. Setelah didapat hasil pretest peserta didik kemedian di uji normalitas dan momogenitas sebagai uji prasayarat untuk uji ANOVA dua jalur.

Tabel 7. Hasil Uji Normalitas Data Pretest

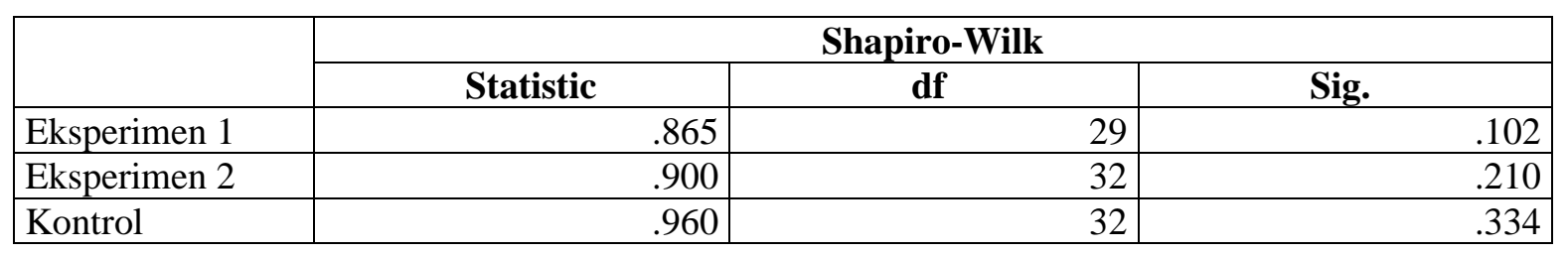

Tabel 8. Hasil Uji Homogenitas Data Pretest

\begin{tabular}{|r|r|r|r|}
\hline Levene Statistic & df1 & df2 & Sig. \\
\hline 2.508 & 2 & 90 & .087 \\
\hline
\end{tabular}

Terlihat pada Tabel 7 hasil uji normalitas data pretest peserta didik di atas menunjukkan nilai signifikansi setiap kelas $<0.05$, maka data pretest berdistribusi normal. Sedangkan pada Tabel 8 hasil uji homogenitas pretest peserta didik menjukkan nilai signifikansi $0.87<0.05$, maka data pretest berdistribusi homogen. Setelah didapat hasil pretest peserta didik setip kelas, kemudian setiap kelas diberikan perlakuan yang berbeda sesuai dengan rancanagan penelitian. Diakhir proses pembelajaran peserta didik diberikan soal postest. Setelah didapat nilai postest setiap kelas, kemudian di uji ANOVA dua jalur berikut hasil uji ANOVA dua jalur. 
Tabel 9. Hasil Uji ANOVA Dua Jalur

\begin{tabular}{|l|l|l|r|r|r|r|}
\hline \multicolumn{7}{|l|}{ Tests of Between-Subjects Effects } \\
\hline Dependent Variable: Kemampuan Pemecahan Masalah \\
\hline Source & $\begin{array}{c}\text { Type III Sum } \\
\text { of Squares }\end{array}$ & $\mathrm{df}$ & $\begin{array}{c}\text { Mean } \\
\text { Square }\end{array}$ & $\mathrm{F}$ & Sig. \\
\hline \multirow{3}{*}{ Intercept } & Hypothesis & 592821.117 & 1 & 592821.117 & 9032.93 & .000 \\
\cline { 2 - 8 } & Error & 136.987 & 2.087 & $65.629^{\mathrm{a}}$ & & \\
\hline \multirow{2}{*}{ Kelas } & Hypothesis & 2644.795 & 2 & 1322.397 & 158.012 & .000 \\
\cline { 2 - 8 } & Error & 54.879 & 6.557 & $8.369^{\mathrm{b}}$ & & \\
\hline \multirow{2}{*}{ GayaBelajar } & Hypothesis & 131.044 & 2 & 65.522 & 9.200 & .025 \\
\cline { 2 - 8 } & Error & 32.626 & 4.581 & $7.122^{\mathrm{c}}$ & & \\
\hline $\begin{array}{l}\text { Kelas * } \\
\text { GayaBelajar }\end{array}$ & Hypothesis & 26.792 & 4 & 6.698 & .094 & .984 \\
\cline { 2 - 8 } & Error & 5961.996 & 84 & $70.976^{\mathrm{d}}$ & & \\
\hline
\end{tabular}

Berdasarkan Tabel 9 hasil ANOVA dua jalur dari hasil posttest kemampuan pemecahan masalah peserta didik kelas X-1, X-2, dan X-3 setelah diajarkan dengan pembelajaran PACE, PACE ditambah media, dan pembelajaran konvensional didapatkan hasil bahwa Ho diterima. Nilai signifikansinya adalah $0.00<0.05$, dengan kata lain terdapat pengaruh penerapan model pembelajaran PACE terhadap kemampuan pemecahan masalah matematis peserta didik. Jika dibandingkan dua kelas eksperimen yang sama-sama menggunakan model pembelajaran PACE maka nilai rata-rata eksperimen II yaitu kelas yang menggunakan model pembelajaran PACE yang ditambahkan media lebih tinggi dibandingkan kelas eksperimen I yang menggunakan model pembelajaran PACE saja. Sejalan dengan pendapat (Suryana, 2013) menyatakan bahwa perbedaan kemampuan pemecahan masalah matematis peserta didik yang terjadi pada kelas yang menerapkan model PACE dengan kelas yang menerapkan pembelajaran konvensional tersebut karena adanya proses pembelajaran yang berbeda ketika kegiatan pembelajaran matematika berlangsung. Pada kelas yang menerapkan pembelajaran PACE, peserta didik memiliki banyak kesempatan untuk melatih serta mengembangkan kemampuan pemecahan masalah matematis melalui kegiatan Project, Activity, Cooperative learning, dan Exercise sejalan dengan penelitian (Suryana, 2015). Model PACE menyediakan banyak kesempatan kepada peserta didik dalam mengembangkan kemampuan penalaran dan komunikasi matematis mereka, untuk mengeksplorasi, mencari solusi, mengkomunikasikan gagasan, mengadaptasi prosedur penyelesaian, serta bekerja dalam kelompok (Rahman \& Yunita, 2018).

Selain itu, penerapan model PACE dalam pembelajaran matematika juga menjadi salah satu alternatif untuk mengembangkan ide-ide kreatif yang dimiliki peserta didik dalam menyelesaikan masalah dan mengkomunikasikan hasil penyelesaian masalah yang dikerjakan. Salah satu model untuk dapat meningkatkan kemampuan berpikir kreatif matematis adalah model pembelajaran PACE (Wardhani, 2015) . Sehingga, kemampuan pemecahan masalah matematis peserta didik di sekolah dipengaruhi oleh adanya penerapan model pembelajaran PACE pada proses pembelajaran matematika.

Terlihat juga dari Tabel 9 juga terlihat nilai signifikansi terhadap gaya belajar adalah $0.02<0.05$, dengan kata lain terdapat pengaruh kemampuan pemecahan masalah matematis peserta didik yang ditinjau 
dari gaya belajar. Hasil analisis data diperoleh bahwa terdapat perbedaan antara kemampuan pemecahan masalah matematis peserta didik yang memiliki gaya belajar visual, auditori, dan kinestetik.

Berdasarkan hasil analisis tersebut terlihat bahwa kemampuan pemecahan masalah matematis peserta didik yang memiliki gaya belajar visual lebih baik dibandingkan dengan kemampuan pemecahan masalah matematis peserta didik yang memiliki gaya belajar auditori dan kinestetik pada semua kelas sampel yaitu kelas eksperimen I, eksperimen II, dan kontrol. Hal ini berarti, dengan atau tidak menerapkannya model PACE dalam pembelajaran tidak bergantung pada jenis gaya belajar yang dimiliki peserta didik karena kemampuan pemecahan masalah matematis peserta didik yang memiliki gaya belajar visual dan menerapkan model pembelajaran PACE ataupun konvensional selalu lebih baik dibandingkan dengan kemampuan pemecahan masalah matematis peserta didik yang memiliki gaya belajar auditori maupun kinestetik dan menerapkan model pembelajaran PACE ataupun konvensional. Hal ini karena peserta didik yang memiliki gaya belajar visual memiliki ciri-ciri mudah menyampaikan idenya melalui tulisan atau gambar. Peserta didik yang memiliki gaya belajar visual memiliki banyak cara untuk menyampaikan ide atau gagasan yang dimiliki dalam menyelesaikan masalah matematika dibandingkan dengan peserta didik yang memiliki gaya belajar auditori dan kinestetik (Danaryanti \& Noviani, 2015).

Pada pembelajaran yang menerapkan model PACE ditambahkan media, peserta didik memiliki banyak kesempatan untuk mencoba menuliskan penyelesaian dari masalah tidak rutin melalui LKPD sehingga peserta didik dengan gaya belajar visual lebih mudah memahami dan mengingat dengan apa yang sudah ditulisnya. Peserta didik dengan gaya belajar visual cenderung lebih khusus dalam belajar dengan selalu melihat pada fokus telaahnya (Henri, 2018). Selanjutnya, peserta didik dengan gaya belajar auditori memiliki ciri dimana merasa bahwa untuk menyampaikan sesuatu dengan menulis itu sulit, tetapi pandai bercerita (DePorter, 2006). Kemudian, salah satu ciri-ciri seseorang memiliki gaya belajar kinestetik adalah membuat keputusan berdasarkan perasaan. Sehingga, dengan demikian kemampuan pemecahan masalah matematis antara peserta didik pada sekolah level atas yang memiliki gaya belajar visual, auditori, dan kinestetik memiliki perbedaan yang signifikan.

Berdasarkan hasil uji interaksi berdasarkan uji ANOVA dua jalur nilai signifikansinya adalah $0.98<$ 0.05, diperoleh kesimpulan bahwa tidak terdapat interaksi antara model pembelajaran dan gaya belajar dalam mempengaruhi kemampuan pemecahan masalah matematis peserta didik. Artinya, penerapan model PACE dan gaya belajar secara bersama-sama tidak berpengaruh terhadap kemampuan pemecahan masalah matematis peserta didik. Pada penelitian ini, penggunaan gaya belajar visual, auditori, dan kinestetik tidak berpengaruh terhadap kemampuan pemecahan masalah matematis namun model pembelajaran PACE memberikan banyak kesempatan kepada peserta didik untuk melatih dan mengembangkan kemampuan pemecahan masalah matematisnya. Penggunaan metode pembelajaran berbasis masalah dan gaya belajar secara bersama-sama tidak berpengaruh terhadap kemampuan pemecahan masalah matematis [9].

Pada penelitian ini juga mengungkapkan bahwa tinggi atau rendahya kemampuan pemecahan masalah matematis peserta didik tidak dipengaruhi oleh penerapan model pembelajaran PACE dan gaya belajar visual, auditori, dan kinestetik karena peserta didik dengan gaya belajar visual yang mengikuti 
pembelajaran dengan model PACE dari pada peserta didik dengan gaya belajar auditori dan kinestetik sejalan dengan pendapat (Rahayuningsih, 2016). Hal serupa juga dialami peserta didik yang tidak menerapkan pembelajaran PACE bahwa peserta didik dengan gaya belajar visual memiliki kemampuan pemecahan masalah matematis lebih baik daripada peserta didik dengan gaya belajar auditori dan kinestetik (Wardhani, 2015)

Hasil penelitian yang tidak sesuai dengan apa yang diharapkan ini berbeda dengan hasil penelitian (Nofrianto et al., 2016) yang menunjukkan bahwa terdapat interaksi antara model pembelajaran dan gaya belajar audio, visual, dan kinestetik terhadap keterampilan proses sains peserta didik. Hal ini terjadi karena antara penelitian Hasyim, dkk dengan penelitian ini menerapkan model pembelajaran yang berbeda untuk kelas eksperimennya. Pada penelitian Hasyim menerapkan model pembelajaran langsung untuk kelas eksperimen, dimana pembelajaran langsung dirancang khusus untuk mengembangkan aktivitas sains peserta didik. Sedangkan pada penelitian ini menerapkan model pembelajaran PACE yang dirancang khusus untuk mengembangkan kemampuan pemecahan matematis peserta didik.

\section{KESIMPULAN}

Kesimpulan bahwa tidak terdapat interaksi antara model pembelajaran dan gaya belajar dalam mempengaruhi kemampuan pemecahan masalah matematis peserta didik. Artinya, penerapan model PACE dan gaya belajar secara bersama-sama tidak berpengaruh terhadap kemampuan pemecahan masalah matematis peserta didik, berdasarkan uji ANOVA dua jalur nilai signifikansinya adalah $0.98<0.05$.

Saran pada penelitian selanjutnya untuk melihat pengaruh penggunakan model pembelajaran PACE dan gaya belajar terhadap kemampuan memecahkan masalah, diperlukan istrumen selain soal tes untuk melihat kemampuan pemecahan masalah.

\section{REFERENSI}

Danaryanti, A., \& Noviani, H. (2015). Pengaruh Gaya Belajar Matematika Siswa Kelas VII terhadap Kemampuan Komunikasi Matematis di SMP. EDU-MAT: Jurnal Pendidikan Matematika, 3(2).

DePorter, B. (2006). Quantum learning: Membiasakan belajar nyaman dan menyenangkan.

Ersoy, E. (2016). Problem solving and its teaching in mathematics. The Online Journal of New Horizons in Education, 6(2), 79-87.

Fadlurreja, R., Dewi, N., R., \& Ridlo, S. (2019). Kemampuan Penalaran Matematis Siswa melalui Model. $2,616-621$.

Fadlurreja, R., Dewi, N. R., \& Ridlo, S. (2019). Kemampuan Penalaran Matematis Siswa melalui Model Pembelajaran PACE. PRISMA, Prosiding Seminar Nasional Matematika, 2, 616-621.

Henri, H. (2018). Pengaruh model co-op co-op mandiri terhadap kemampuan pemecahan masalah ditinjau dari gaya belajar siswa. AKSIOMA: Jurnal Program Studi Pendidikan Matematika, 7(3), 482-491.

NCTM. (2000). Principles and Standards for School Mathematics Overview. Journal of Equine Veterinary Science. 
Nofrianto, A., Susanti, W., \& Amri, M. A. (2016). Peningkatan Kemampuan Pemecahan Masalah Matematika Siswa Melalui Model Pembelajaran Laps-Heuristic Dikelas X SMAN 2 Batang Anai. Jurnal Gantang, 1(2), 39-50.

Permendikbud. (2016). Peraturan Menteri Pendidikan Dan Kebudayaan Nomor 21 Tahun 2016 Tentang Standar Isi Pendidikan Dasar Dan Menengah. Revista Brasileira de Ergonomia.

Putra, A. L. T., Dwidayati, N. K., \& Isnarto, I. (2020). Problem-Solving Ability in terms of Adversity Quotient On SFE Learning Based on Firing Line. Unnes Journal of Mathematics Education Research, 9(1), 78-85.

Rachmawati, I. A., Triyanto, T., \& Chrisnawati, H. E. (2018). Eksperimentasi Model Pembelajaran Student Teams Achievement Division Dengan Pendekatan Scientific Pada Materi Bentuk Aljabar Ditinjau Dari Gaya Belajar Siswa Kelas VII SMP Negeri 11 Surakarta Tahun Pelajaran 2017/2018. Jurnal Pendidikan Matematika Dan Matematika SOLUSI, 2(2), 134-144.

Raharjo, J. F. (2017). Mengembangkan Kemampuan Berpikir Aljabar dan Kemandirian Belajar Mahasiswa Melalui Pendekatan Saintifik Model Pace pada Mata Kuliah Struktur Aljabar. JIPMat. https://doi.org/10.26877/jipmat.v1i2.1240

Rahayuningsih, S. (2016). Meminimalisir Kesalahan Konsep Kombinatorik melalui Pembelajaran Pace. Likhitaprajna, 18(2), 67-78.

Rahman, A. A., \& Yunita, A. (2018). Penerapan Model Pembelajaran Pace Untuk Meningkatkan Kemampuan Pembuktian Matematika Siswa Di Kelas Vii Smp Materi Geometri. MAJU: Jurnal Ilmiah Pendidikan Matematika, 5(1).

Sundayana, R. (2016). Kaitan antara gaya belajar, kemandirian belajar, dan kemampuan pemecahan masalah siswa SMP dalam pelajaran matematika. Mosharafa: Jurnal Pendidikan Matematika, 5(2), $75-84$.

Suryana, A. (2015). Analisis Implementasi Model PACE pada Mata Kuliah Statistika Matematika. JKPM (Jurnal Kajian Pendidikan Matematika), 1(1), 91-105.

Suryana, A. (2013). Penerapan Model Pembelajaranpace Dalam Meningkatkan kemampuan Berpikir Kreatif Matematis. Seminar Nasional UNIVERSITAS, 11.

Wardhani, I. S. (2015). Menumbuhkan tindak pikir kreatif melalui model pembelajaran pace. JP2M (Jurnal Pendidikan Dan Pembelajaran Matematika), 1(2), 31-45. 